\title{
Drone warfare and contemporary strategy making: Does the tail wag the dog?
}

\section{Metin Gurcan}

To cite this article: Metin Gurcan (2013) Drone warfare and contemporary strategy making: Does the tail wag the dog?, Dynamics of Asymmetric Conflict, 6:1-3, 153-167, DOI: 10.1080/17467586.2013.859284

To link to this article: http://dx.doi.org/10.1080/17467586.2013.859284

曲 Published online: 27 Nov 2013.

Submit your article to this journal $\pi$

Џll Article views: 930

Q View related articles ๘ 


\title{
IDEA PAPER
}

\section{Drone warfare and contemporary strategy making: Does the tail wag the dog?}

\author{
Metin Gurcan* \\ Department of Political Science, Bilkent University, Turkey
}

(Received 22 October 2013; accepted 22 October 2013)

\begin{abstract}
In the traditional Clausewitzian view, political goals and policies determine the character of war, and consequently policy forms the frame in which military strategy is shaped. This paper questions whether current experience has undermined the subjugation of military technique to military strategy, and thus to policy. The example of armed drones suggests that new technique can change the nature of war, including political and ethical views of war. An earlier example of new technique - nuclear weapons - brought similarly broad changes. Against one-way determinist views of the power of new technique, I argue that the interaction of armed drones with strategy, culture and politics has barely begun.
\end{abstract}

Keywords: drone warfare; strategy; military technique

"If technology is the answer, what was the question?"

Just after the 9/11 attacks, then US president George W. Bush used the term "War on Terror" for the first time, ${ }^{1}$ and began to wage a war against al-Qaida-led extremist networks. This "asymmetric" war has caused the emergence of new modes of thinking in the theorization of warfare and new practices in the conduct of it. ${ }^{2}$ Notable in the new way of warfare is the thrust of military technique upon strategy-making. For David Frum and Richard Perle, for instance, two heavyweight US strategists in the neo-conservative camp, military dominance abroad and unlimited use of soldiers, computers, remote sensors and unmanned airplanes are required for victory against terrorism. ${ }^{3}$ Their emphasis on ways and means does not begin with an analysis of strategy proceeding from political goals; that is, Frum and Perle do not follow the traditional subordination of means to ends. They do not begin from a political analysis of terrorism or define what victory over terrorism would look like.

In this paper, I refer to military technique to include both the new modes of technology in warfare (means) and the military's tactical expertise in implementing technology in the battle space (ways). My goal is to show how technique has begun to determine strategy rather than the other way round.

It is worth mentioning immediately the distinction between grand strategy and military strategy. Grand strategy is, with Liddell Hart's words, "the higher strategy which is to coordinate and direct all resources of a nation towards the attainment of the political objectives of war - the goal defined by fundamental policy." 4 On the other hand, military

*Email: metin.gurcan@ bilkent.edu.tr 
strategy refers to the conduct of warfare with military technique (both ways and means). Indeed, in the Clausewitzian tradition I will describe further, strategists identify military strategy as the mere instrument of grand strategy-making. Thus, policy determines the character of war, and consequently policy forms the frame in which military strategy is shaped.

The overall objective of this paper is to question the extent to which military technique is subjugated to military strategy, and thus to policy. That is, I seek to elucidate - in Colin S. Gray's formulation - whether "the weapons are mere instruments with which war is conducted, or they decide the war." In order to show the controversy over how far military technique has encroached upon strategy, the first section of this paper briefly describes the classical Clausewitzian view in which technique is subordinate to strategy, and contrasts this view with several recent arguments that technique is the determinant, not the result, of policy and strategy decisions. The second section looks at armed drones as an example that seems to show technique affecting strategy and politics. The third section represents the work of Paul Virilio, who has theorized that speed-of-light war has no room for democratic political decisions. Finally, I suggest that both those who like and those who fear the political effects of drone warfare are exaggerating the extent to which technique determines politics and strategy. Armed drones, like atomic bombs, will have very different political and ethical meaning when the current US monopoly wanes.

\section{War as politics by other means - or not?}

It has always been difficult to develop a description of war that is both sufficient and necessary. ${ }^{6}$ However, one can observe that war is the application of collective organized violence in pursuit of political objectives; that is, with Carl von Clausewitz's famous words, "war is the continuation of politics by other means."7

Translating political objectives of grand strategy into the operational missions in the military strategy is the process of setting operational objectives for campaigns, and from there tactical missions for battles. The other side of this process is the provision of resources with which to do the job, and deciding how to employ those resources. There is thus a cascading series of aims and the concomitant provision of means in a hierarchical fashion. Putting more emphasis on military strategy, Clausewitz described this process as the "dialectic" of aims and means management that is achieved through a strategy.

B. Henry Liddell Hart, putting less emphasis on military strategy than policy, defines strategy as "the art of distributing and applying military means to fulfill the ends of policy". ${ }^{8}$ One should, nonetheless, note that both gave the pre-eminence to political aims over military means. That is, in Clausewitz's enduring words, "the political object - the original motive for the war - will thus determine both the military objective to be reached and the amount of effort it requires." One may then suggest that this traditional understanding of technique refers to instrumentality of technology in strategy-making.

In an apparently similar formulation, Colin S. Gray sees strategy as "the bridge that relates military power to political purpose; it is neither military power per se nor political purpose."10 For Gray, however, strategy should focus more on "exercising power effectively to adapt constantly to the shifting conditions of the battlefield,"11 and Gray thus refers more to the conduct of warfare (or military technique) rather than policy-making.

Following a narrower conceptualization of strategy and putting more emphasis on the agency of technique, British Colonel Charles E. Calwell suggested in the earlier twentieth century that "strategy is not the final arbiter in war. The battlefield decides." ${ }^{\text {12 }}$ Following Colonel Calwell's emphasis on the importance of the battlefield - the importance of soldiers 
and their weapons, the importance of technique - some modern strategists tend to believe that the entire concept behind policy driving war falls apart in light of modern and future motivations for war. In the twenty-first century, Steven Metz believes "war will be fought not to pursue national interests, but solely to kill enemy leaders [targeted assassinations], to convert opponents to one's religion, or, sometimes, for simple entertainment."

Taking Metz's formulation one step further, Peter W. Singer suggests that the change is not solely about how wars are fought, but about the politics, laws, economics and ethics that surround war itself, and then contends that the "techno-scientific" revolution is the "driver of this change." ${ }^{13}$ In his book entitled Wired for War where he formulated much of his argumentation on the future of warfare, Singer states:

It sounds like science fiction, but it is fact: On the battlefields of Iraq and Afghanistan, robots are killing America's enemies and saving American lives. But today's PackBots, Predators, and Ravens are relatively primitive machines. The coming generation of "war-bots" will be immensely more sophisticated, and their development raises troubling new questions about how and when we wage war. ${ }^{14}$

The Baltimore Sun newspaper introduced Singer's book with these remarks:

a future already unfolding in the skies over Iraq, Afghanistan and Pakistan, where unmanned drones scan the ground below and blow up people as determined by pilots thousands of miles away. Sci-fi is becoming battlefield reality, and Mr. Singer makes it clear that this is just the beginning. Robotic warfare raises lots of profound questions about how wars are to be fought. ${ }^{15}$

The dream of eliminating Clausewitz's "fog of war" is longstanding. Removing unpredictability, increasing lethality with high-precision weapons, increasing the tempo of warfare, and reducing casualties have always been the prime objectives of military decision makers and strategy planners. Lowering the economic and political costs of war have also been key considerations that fundamentally affect the strategy making process. Thus, for almost three decades, the concept of "Revolution in Military Affairs" (RMA), ${ }^{16}$ which mainly characterizes the use and incorporation of information technologies to enhance war fighting capacities, has been widely discussed among strategy-makers.

In Operation Desert Storm, for instance, the US-led war against Saddam Hussein's Iraq in 1991, the use of GPS- or laser-guided weapons delivered by stealth fighters dominated TV coverage and created the perception that the operation was surgically clean thanks to the RMA. Particularly after the Kosovo War in 1999, in which US forces did not lose a single soldier, many suggested that war had become too sterile, creating an almost "Virtual War," 17 which refers to a form of warfare that is experienced primarily as a series of visual images and representations.

In tandem with the notions of RMA and virtual war, the concept of a new Western Way of War has also become increasingly common in contemporary debates over the nature of warfare. For Der Derian, the key feature of virtuality is not its ability to mimic reality, but to create new realities. These newly emerged virtual wars, for him, "create new realities of conflict through reliance on information, the ability to overcome physical distance through the speed of information transfer allowed by new technologies, and, crucially, through the prevalence of forms of simulation."18 This final characteristic of virtual war, simulation, has been a common feature of the Western Way of Warfare. Simulations are generally viewed as mere preparations for or representations of real-time experience, but many practitioners argue that they help to produce and delimit new practices of warfare through holistic training and hyper-real modeling, in which the distinctions between the simulated and the real begin to break down. 
Jean Baudrillard, who argues that increased forms of simulation "threatens the difference between true and false, between real and imaginary," ${ }^{19}$ took this logic to the extreme by declaring that the Gulf War in 1991 did not actually take place. For him, the heavily mediated nature of the Gulf War meant that the majority of soldiers sitting in front of their computer screens and looking through night-vision goggles did not actually experience the reality of the battle field. They only experienced the Gulf War as a series of images and representations, which effectively superseded the actual reality.

As an officer who served in Afghanistan in 2005 and several times in Iraq between 1999 and 2003, and who trained host-nation soldiers in several countries, I fully appreciate that one man's account of the battlefield cannot be the whole truth of war. Nevertheless, I would suggest that this phenomenon of alienation from actual reality, with increasing embrace of virtuality and tele-presence, was very visible in all operational theaters I experienced. The fact that my view of the failure of counterinsurgency efforts in Afghanistan was selected as the Quote of the Year in 2011 by the Small Wars Journal Community, the broad and well-regarded online community where many soldiers from all around the world share their experiences, suggests that I am not alone in my concern.

\begin{abstract}
If the numbers of the Counterinsurgency (COIN) soldiers who are watching the war from their screens are more than the numbers of soldiers who see the pupils of the insurgents with their own eyes, COIN cannot disrupt this insurgency. Stated another way, the more soldiers you have fighting the insurgency from behind their screens in their hi-tech bubbles, instead of fighting on the ground in the theater of war, the more easily you fall into this trap. If COIN soldiers are not able to see, smell, taste, and, more importantly, feel the theater (by saying feeling the theater I mean to fully understand the terrain and weather conditions, and the agonies, perceptions, motivations, hatred, happiness of the local people who live in it) they experience a sort of alienation from the reality on the ground. ${ }^{20}$
\end{abstract}

This phenomenon of alienation from the actual reality at the tactical level has surely had important consequences. One obvious consequence is an overemphasis of military capabilities in the METT-TC (Mission, Enemy, Terrain, Troops available, Time, and Civilian considerations). At the tactical level, this acronym helps team, company and battalion commanders remember and prioritize what to analyze. During the planning phase of an operation at the tactical level, the relative rise of the military capabilities (Troops available) in the METT-TC has caused a decline of the importance of the considerations of enemy, terrain, time and civilian thanks to the technological developments. Hi-tech military assets, which triumph over weather, terrain and demographic constraints to provide a diligent situational awareness, stimulate the strategist to concentrate solely on choosing the most appropriate military capability for the designated mission. Agreeing with this assessment and carrying it to the strategic level, Colin S. Gray suggests that the RMA that stresses the "unlimited" use of military technique has increased effectiveness of hi-tech militaries, and thus has led to capabilitybased planning in strategy-making. ${ }^{21}$

Thus Drone Warfare, which indicates the strengthened position of technique over strategy, provides a useful test case for better understanding the impact of the capabilityfirst approach in military strategy.

\title{
The armed drone: hi-tech life-saver or new impetus to violence?
}

Thanks to new military technique, the features of eagle sighting in all weather conditions, real-time imaging, automated mode of target acquisition, precision guidance, unmannedness, tele-command, and extreme lethal capabilities have been collected in armed drones that have emerged as the force multiplier of post-heroic warfare. ${ }^{22}$ Relying 
on armed drones' sophisticated day and night vision capabilities, "tele-spectator soldiers" who see suspicious activity can easily engage with the suspicious image on their screen and send missiles toward it with a gentle move of the joystick and a simple touch of its button. $^{23}$ Armed drones have also been employed in critical missions to conduct extrajudicial targeted killings of suspected individuals around the globe. ${ }^{24}$

These capabilities have turned armed drones into weapons of choice for asymmetric conflicts. Since 2005, for instance, the Pentagon's drone's flights tripled from about $170,000 \mathrm{~h}$ to more than $570,000 \mathrm{~h}$ in 2011 , with the annual budget for drones growing from $\$ 1.9$ billion in 2006 to $\$ 4.8$ billion in 2010 . In the same period, the drones' numbers in the US Military have gone from under 3100 to more than $6500 .^{25}$ In 2008, for instance, armed drones flew over Iraq and Afghanistan for $140,000 \mathrm{~h}$ (equivalent to 16 years of flight) and dropped 189 missiles in numerous air attacks that claimed the lives of 3000 people, ${ }^{26}$ the great majority of whom were civilians - the "collateral damage" or unintended consequence of drone warfare. It is also worth mentioning that, following the fashion, China, Russia, India, UK, France, Germany, Canada, Israel and many more countries have been looking forward to expanding their know-how on drone-related technologies and increasing their numbers of drones in service. ${ }^{27}$

The ability to hit a suspicious van moving at the speed of 60 miles per hour from roughly 8 miles away with exact precision is as crucial as pushing the "fire" button on the joystick from 8000 miles away. The "tele-spectator" soldier who has already owned the space and sight with technique, this time gains omnipotence with the decisively lethal guided missile systems that have the capacity to turn any image on the screen to ashes within the range of 10 miles in $15-20 \mathrm{~s}^{28}$ As US Colonel Theodor Osowski reveals in his Biblical metaphor: "It's kind of like having God overhead. And lightning shows up in the form of a Hellfire."29

Starting on 23 April 2011, US drones commenced six months of strikes against Qaddafi's wavering regime in Libya. Crucially, these strikes implemented in the territory of a nation state were not authorized by the so-called "War Powers Resolution" 30 of the US Congress that was designed to curb executive war powers. Neither were the drone strikes in Iraq and Afghanistan authorized by Congress. Seeing the effectiveness of the drone warfare in the so-called "War on Terror" campaigns, Peter W. Singer writes in an optimistic fashion "And now we possess a technology that removes the last political barriers to war." ${ }^{31}$ He adds that:

For the first 200 years of American democracy, engaging in combat and bearing risk - both personal and political - went hand in hand. In the age of drones, that is no longer the case. Like it or not, the new standard we've established ... is that presidents need to seek approval only for operations that send people into harm's way - not for those that involve waging war by other means." 32

It is certain that, with its physical limitations, the human body is not capable of matching the speed and lethality of drones. The agency of military technique is so assertive that one may easily suggest that technological systems have come to dominate military strategy and reverse the traditional dictum of subjugation of technique to policy and politics.

\section{Military technique determines political reality}

Indeed, some critical thinkers believe that technology creates not just strategy and policy, but its own social reality. Paul Virilio, French philosopher and critical military thinker, asserts that in human history has seen three major stages of war. These are as follows. 
1. Pre-historical and Tactical Stage that includes limited violence. We have "weapons of obstruction" in this first stage such as trenches, strongholds, armors and fortifications of all sorts.

2. Second is the excessively industrial and purely political Strategic Clausewitzian Stage. In this stage, we notice new "weapons of destruction" such as firearms, machine guns, cannons, tanks and missiles. We also notice the importance of economics and logistics in putting industrial power behind large citizen armies. Beginning with the French Revolution, countries that could mobilize a citizen army dominated countries relying on a professional army. Thus, in the Second Stage, democratic politics was a military necessity; a "nation in arms" requires a considerable degree of social and political consensus.

3. Third is the Contemporary and Trans-political Logistical Stage. In this stage, science and technology play a decisive and determining role in the destructive power of conflicting sides. One notices new "weapons of communications" in this stage, such as signals and information acquired through radars, optical and acoustic devices, and satellites. This is, in fact, the stage of weapons of instantaneous communication that have come to govern the battlefield, thanks to the rise of globally connected information networks and tele-surveillance. In this stage, the destruction power has been transferred from armed subjects to complex weapon systems that kill at a distance. In this stage, in military terms, weapons of war (planes, missiles, tanks) depend on remote imaging, radar echo, or thermal signature. These weapon systems have been subjected to a clear-cut imperative of remoteness and non-detection, including characteristics of maneuverability, small size, high velocity, and weak radar return.

Virilio emphasizes that the strategic alliance of industrial, scientific and military communities has drastically changed the nature and extent of warfare in the Contemporary era. In particular, the lethal "scientification" of warfare is accepted for the sake of greater speed and autonomy, but ends up with the celebration of military technique that subjugates perceptual, bodily and creative modes of thinking that used to be forms of human experience in the battlefield. ${ }^{33}$ Virilio warns that our "strategic interaction technological systems shape our culture and our interaction with the environment; modify patterns of human action, influence who we are and how we live."34

Virilio develops the term "dromology,"35 that critically examines the role and function of speed in history and its function in socio-political life. ${ }^{36}$ Interestingly, he asserts that no politics is possible and thus there is no place for democracy at the speed of light, ${ }^{37}$ and then continues to emphasize the significance of speed:

Politics depends upon having time for reflection. Today, we no longer have time for reflection.

Today, we no longer have time to reflect, the things that we see have already happened ${ }^{38}$

He then concludes that since "Totalitarianism is latent in technology," a "real-time democracy" is not required as in Stage Two. "Weapons of communications" in the Contemporary Stage acquire information from radars, optical and acoustic devices and satellites that operate near instantaneously, at the speed of light. Command and control communication is also nearly instantaneous, thanks to the rise of globally connected information networks. In this stage, in military terms, the physical material of war (planes, missiles, tanks, torpedoes) depends on weapons of communication. These combat systems have been subjected to a weapons-of-communications imperative of remoteness and non-detectability, including characteristics of maneuverability, high velocity, and weak 
radar return. Therefore, the central goal "of this new war game becomes first look, first shot and first kill." 40 Who is detected first, dies first.

In traditional terms, the initial occupation of a weapon is the eye, or sighting. Before conquering his target, a soldier must constantly take aim, to bring into line his target between his eye and the sight of the weapon. Today, however, for Virilio, the difference is "indirect sighting", the tele-sighting that no longer works with naked eye and bodily experience, but with electro-magnetic waves at the speed of light. The display of the "image" of target on the control monitors or computer monitors causes a mediated perception (tele-imaging with video or radar), not an immediate perception (with one's own eyes), which is, for Virilio, "a kind of intoxication of perception." 41

In this stage, every type of military machine lies within two categories of the "real" in terms of target acquisition: the actual presentation - the object is there and it is identified optically (eye) and acoustically (ear). And, the virtual representation - the object - is not indeed there in physical terms, but it has been spotted and monitored on the screen. ${ }^{42}$ To sum up, in this new epoch, not the actual target but its representation in pixels is the important sighting for "tele-spectator soldiers" sitting before their screens in their airconditioned OCs (Operation Centers). Virilio argues that these tele-spectator soldiers will be the ones who will make war in the future and "paint the electronic battle fields." 43

In a similar fashion, Simon Glezos describes the post-9/11 security environment with the following words:

\begin{abstract}
We were told that we could not afford to wait and allow "the smoking gun to come in the form of a mushroom cloud." Implicit in this quote, and countless others like it, was an exposition of the new temporal order of the political world, the pace with which new threats can materialize leaves no room for hesitation. Decisions must be made quickly and effectively by a centralized and authoritative executive. Slow moving processes of deliberation and political debate are no longer viable. ${ }^{44}$
\end{abstract}

As seen in the drone case, there emerge two contradicting interpretations on the role of technique in military strategy. An optimistic interpretation attaches positive value to the determining role of technique, a pessimistic interpretation presents a gloomy picture of the determining the role of technique. Both, however, by accepting technique as the escapable destiny, present an "essentialist" understanding of technique, which constitutes the second variant of understanding of technology after traditional instrumentalist variant. The essentialist variant suggests that technology causes social change in a deterministic fashion and military technique fills the frame of strategy to the detriment of politics.

It is then appropriate to ask: to what extent is it justified to sacrifice "effectiveness," the magical word proposed by optimist essentialists and measured with instantaneity and greater weapon autonomy, for the sake of time-sucking and dependency-creating political procedures? Or, to what extent is it still relevant to assert that drone warfare is simply another means for policy to play its merely "instrumental" role in strategy-making? In short, as suggested by the case of armed drones, do we witness the declining role of policy in strategy-making due to technological necessity?

\title{
Evolving interaction of technique with politics and policy: the atom bomb example
}

To better answer the questions stated above, some reflections about the impact of nuclear weapons on strategy making can provide relevant insights. The reason for concentrating on nuclear weapons is the widespread perception that they represent a major change, indeed a revolution, not only in warfare but also in the relationship between "social reality" and technique. 
As seen in the section on armed drones, there are mainly two different conceptualizations of the relationship between technology and society: the instrumental and the essentialist. To reprise them, the instrumental view posits that technology is a neutral medium or means; the substantive view argues that, far from being neutral, technology inexorably determines social relations in a particular way.

The instrumental approach has viewed nuclear weapons in what may be termed the National Rifle Association perspective. This “It isn't the nuke, it's the person [state] holding the nuke" approach assumes that nuclear weapons in the hands of free, civilized and democratic Western states could be deployed in such a way as to deter potential aggressors against the freedom and prosperity that the Western World cherishes. Gray, for instance, in his book titled "Weapons Don't Make War," states that "all weapons are created equal and have equivalent consequences according to their technical qualities but regardless of their political ownership., 45

The essentialist approach, which implies that technology has an autonomous logic of its own that determines particular forms of social organization, suggests that a nuclear weapon is so lethal that its potential effects override all other political, social and cultural considerations in the calculations of decision-makers. In short, the presence of nuclear weapons inevitably moderates the behavior of states. In a paper subtitled "More May Be Better," Waltz, for instance, argues that because of the technologically determined, pacifying nature of nuclear weapons, their benefits should be spread throughout the international system by gradual proliferation. ${ }^{46}$

The pessimist camp in the essentialist approach, on the other hand, rejects the view that the autonomous logic of nuclear weapons technology is benign. Frank Barnaby, for instance, notes that "we are being driven toward nuclear world war by the sheer momentum of military technology." ${ }^{47}$ In the same vein, Edward Thompson notes that "weapons seem to grow of their own accord, as if possessed by an independent will."48

One should recognize, however, that despite their optimistic and pessimistic depictions of nuclear weapons, the common thread in the thinking of Waltz, Barnaby and Thompson is a similar essentialist approach the relationship between human beings and nuclear technology. They all see that technology as an autonomous force shaping social relations and as a universal destiny that overrides cultural particularity.

In fact, most contributions to the literature on nuclear weapons fall into one or other of these two camps. Debates about nuclear weapons break down into one group of scholars arguing that new technologies do not alter the fundamentals of strategy and are simply tools to be used to serve existing ends, versus those who argue that new technologies are not simply new tools but require a radical rethinking of strategic goals and organizations. This dichotomous characterization of technological development - as either being driven by strategic goals on the one hand or determining them on the other - is present not only in academic debates but in the practical promotion and justification of hi-tech weapons systems of many kinds.

Since their first appearance, nuclear weapons were regarded as so qualitatively different from other military assets that everything that came before was defined as "conventional." The most powerful conventional bombs used in World War II contained 10 tons of TNT; the average yield of the Hiroshima and Nagasaki bombs, however, was the equivalent of 18,000 tons of TNT. The first US thermonuclear (H-bomb) test, in November 1952, had a yield of over 10 megatons, almost 580 times the power of the nuclear devices exploded in August 1945. Today, one intercontinental ballistic missile (ICBM) warhead possesses the equivalent of all the explosive power used in all of WWII. $^{49}$ 
Because the nuclear weapon was not the result of existing strategy, the nuclear revolution was a technology-driven RMA. New strategy was developed to determine what role nuclear weapons were to play. According to Andrew Ross:

Initially, the U.S. Army-Air Force (then the USAF after 1947) took the lead; relatively soon, the U.S. Army and the U.S. Navy went nuclear. New military organizations emerged - the Strategic Air Command, for instance. New service elites - strategic bomber pilots and intercontinental ballistic missiles (ICBM) operators in the USAF and nuclear submariners in the USN - appeared. New civilian structures were stood up, including the Atomic Energy Commission, which over time became the Department of Energy; subsequently, we saw the establishment of National Nuclear Security Administration. There were further technological developments. Not only did we go from fission to fusion by 1952, but we also devised new delivery systems, truly intercontinental jet bombers developed relatively quickly during the 1950 s, with the B-52 (which is still with us) making its appearance in the mid-1950s. In between going from bombers to ICBMs, the USAF worked on cruise missiles. The latter weren't particularly successful in the 1950s but reappeared in the 1970s and 1980s. The Navy developed submarine-launched ballistic missiles (SLBMs) that were put on new platforms, nuclear-powered submarines. ${ }^{50}$

In fact, the nuclear revolution had greater strategic than operational or tactical war-fighting implications. The nuclear revolution led to drastic changes in how strategists conceive of deterrence. ${ }^{51}$ Deterrence has surely become nuclear weapons' central role, and the utmost objective of deterrence is to prevent aggression and war. Deterrence entails persuading potential aggressors that the costs and risks of aggression are sure to exceed its benefits. In 1946, as Bernard Brodie, one of the "Wizards of Armageddon" 52 who tailored the US's nuclear strategy, observed: "Thus far the chief purpose of our military establishment has been to win wars. From now on its chief purpose must be to avert them. It can have almost no other purpose." 53

This different conceptualization of strategy required the requisite capabilities and the willingness to use them. ${ }^{54}$ In the conventional sense, however, the strategists have often thought that the ability to deter depended on the ability to fight: to be able to defend oneself and go on the offense effectively. With the appearance of nuclear weapons, emphasis has shifted from maintaining ability to fight to ability to retaliate even after receiving the hardest blow the adversary can deliver. This is about striking second; that is, about being able to absorb a nuclear blow, having forces that would survive, and being able to retaliate and punish the enemy, which implies second strike capability. Punishment is thought to require not only offensive strike capabilities, but also retaliatory, second- (rather than first-) strike capabilities. The emphasis on second-strike capabilities requires survivable forces. Survivability, after the nuclear revolution, is enhanced by dispersing forces, rather than concentrating them, by deploying them underground in concrete, steel-reinforced silos; or by putting them out at sea in submarines that cannot be easily tracked and targeted.

Another difference in the military strategy that emerged with the appearance of nuclear weapons was more involvement of civilians in the strategy-making process. Since the Manhattan Project, civilians - Americans, Canadians, British, Germans - have played a greater role in the nuclear revolution. More importantly, those who were responsible for the systematic exploration and development of US nuclear policy and strategy over the years have been primarily civilians.

Aside from the above-mentioned material and organizational changes, it is not hyperbole to suggest that the nuclear revolution changed the ethical patterns of the strategy makers. Because nuclear bombs often have high civilian death rates, practical military targets are hard to come by and radiation from a single explosion poses health risks to communities worldwide. These concerns led to an ethical question at the strategic level: 
how can a strategist justify creating and improving nuclear weapons technology? The argument that possession of such weapons promotes peace by discouraging countries from entering nuclear war constitutes the ethical basis of the answer. Then, pro-nuclear military strategies suggest that one has to use this means to attain the legitimate ends. Retaining such weapons as long as one's potential enemies possess them, constantly maintaining parity with the other side - in other words, proceeding with the arms race for mutually assured destruction between nuclear powers.

There are even tougher ethical questions. For a strategist, it may be morally acceptable to kill an enemy's civilians to prevent the deaths of his own soldiers. Much debate has occurred throughout the world regarding this issue - both at the time of the first usage of nuclear weapons in Hiroshima on 6 August 1945 during the WWII and continuing today. In the decision to drop the nuclear bomb on Hiroshima, for instance, the American strategists faced a difficult choice. Not using nuclear bombs would prolong the war for several months, and cause the deaths of hundreds of thousands of American soldiers. On the other hand, using nuclear bombs would end the war sooner, and kill hundreds of thousands of Japanese civilians. ${ }^{55}$ Indeed, a land battle would have resulted in heavy losses for both sides, but one must wonder if the Hiroshima atomic bomb actually saved more lives than it destroyed. The consideration, however, that the life of an innocent civilian is morally worth more than the life of a soldier who is paid to go and fight, complicates the matter. ${ }^{56}$

Surely a strategist, when he plans to send an army which includes thousands of soldiers to what is almost certainly their death, has to think in terms of necessity rather than morality. ${ }^{57}$ To decide to sacrifice Hiroshima and eighty thousand civilian "souls" in return for a few months and thousands of Allied soldier's lives is an impossible decision. When in warfare, morality goes and necessity takes over because it is more important to the achieving of victory. Machiavelli proclaimed that reliance on morality was the path to selfdestruction. ${ }^{58}$ However, Hashmi and Lee disagreeing to this Machiavellian dictum suggests that the American generals deciding the drop of atomic bomb in Hiroshima "viewed the bomb as the final, dispute-ending way of proclaiming American national superiority." 59

Returning now to the parallel with military drones, which have been epitomized as the "force multipliers" of contemporary warfare by many military strategists, ${ }^{60}$ nuclear bombs are like military drones in that both brought new strategies into being. Nuclear bombs, once employed for life-saving offense, became the foundation of deterrence strategies by drastically changing how strategists conceptualize the conduct of warfare. Military drones, now employed for life-saving offense as once nuclear bombs were, are bringing new virtual warfare that is already affecting tactical and operational level planning, and will likely bring new strategy formulations to both asymmetric and symmetric warfare. As nuclear weapons brought cultural change and new modes of ethical considerations, expressed in civilian nightmares, international control agreements, and ban-the-bomb movements, so military drones are bringing controversy over virtual killings (mostly civilians) and their consequences for both those who press the buttons and those who do not yet have buttons to press.

The appeal of drone attacks for strategy-makers is clear. First, their effects are measurable and to the point. Many strategists point out that drone attacks have disrupted terrorist networks in many hot spots in the theaters of Pakistan, Afghanistan and Yemen, selectively killing the key leaders and denying the movements of the enemy. Drone attacks create a sense of insecurity among the enemy lines and constrain their interactions with local civilians. Second, because they kill remotely, drone strikes avoid friendly casualties as in the case of nuclear strikes against Japan. 
However, the question to be asked at this point is: at what expense are these strategic benefits achieved? I suggest that the costs overshadow these benefits for three reasons. First, drone warfare has created a siege mentality among civilians in the area of operation. While the strikes did kill individual militants who were the targets, public anger over the American show of force solidified the power of extremists. The Islamists' popularity rose and the group became more extreme, leading eventually to a new regional insurgency. The following remarks of Yemeni journal Farea al-Muslimi, who wrote an article titled "America Loses Yemeni People In Drone War" in the al-Monitor journal, deserve attention:

Even more enraged than urban dwellers were villagers living in towns hit by American drones over the past few days. During the most sacred and festive time of year [In the Month of Ramadan ], the US conducted eight different strikes over a week; the highest rate since US started using drones in Yemen. For the last few days, it has been difficult to follow the drone casualty numbers and to differentiate between strikes. With the public frenzy over the planes hovering over Sanaa and the rapid-fire drone strikes in the countryside, any remaining credibility of the US government's stated intentions to take a comprehensive approach to Yemen's economic and political development has now evaporated. Even Yemen's political elites, who have historically been close allies with the US government, have been pointing fingers at the Americans over the past few days. They all see the US as supporting the transition in one hand and killing it by the other.

While Yemenis have suffered greatly, even perhaps more than Americans, from the Yemenbased branch of al-Qaeda's presence in the country, the US military's hyper-focus on the terrorist group is hugely disproportionate with its actual capabilities. As in the past, America's over-reaction to a potential security threat has only helped al-Qaeda prop up the myth of its widespread influence.

The majority of Yemenis are simply angry because the US seems to have little concern for the real challenges facing the country. Millions of Yemenis live in extreme poverty. The needs for investments in healthcare, education and infrastructure are immense. Meanwhile, the US spends enormous resources on drone strikes that do little more than terrify impoverished villagers and provide undue publicity to al-Qaeda. ${ }^{61}$

These remarks clearly indicate that while violent extremists may be disliked, for a frightened population they seem less threatening than a "faceless enemy" that wages war from afar and often kills more civilians than militants.

Second, public outrage at the strikes is hardly limited to the region in which they take place. Mainly by means of internet and social media access, the strikes are now exciting regional, and in some events global opposition. It is interesting to note that, covered extensively by the news media, drone attacks are popularly believed to have caused even more civilian casualties than is actually the case. The persistence of these attacks on host states' territories offends local people's deepest sensibilities, alienates them from their government, contributes to their state's instability, and strengthens anti-American rhetoric.

Third, and most importantly, although the use of drones displays every characteristic of a tactical-level operation, it creates an "illusion" of short-term tactical-level achievement (mostly killing some key middle- and upper-middle-level leaders) at the expense of long-term strategic consequences. In any counterinsurgency effort, the utmost objective of the counter-insurgency force is to separate violent extremists from populations in which they hide. Relying on my field experience, I full heartedly suggest that the great majority of people don't tolerate extremists in their midst because they like them, but rather because the extremists intimidate them. Breaking the power of extremists means removing their power to intimidate - something that drone strikes cannot do. This 
shortfall, in fact, reflects my "having the capability to blow up a village within a second but not having the capacity to hold this village 24/7" dilemma of Coalition Forces in Afghanistan. ${ }^{62}$ Another strategic consequence of conceptualization of the drone warfare is the "personalization" of warfare, and thus of strategy-making. David Kilcullen states that:

The drone campaign is in fact part of a larger strategic error - our insistence on personalizing this conflict with Al Qaeda and the Taliban. Devoting time and resources toward killing or capturing "high-value" targets - not to mention the bounties placed on their heads - distracts us from larger problems, while turning figures like Baitullah Mehsud, leader of the Pakistani Taliban umbrella group, into Robin Hoods. Our experience in Iraq suggests that the capture or killing of high-value targets - Saddam Hussein or Abu Musab al-Zarqawi - has only a slight and fleeting effect on levels of violence. Killing Mr. Zarqawi bought only 18 days of quiet before Al Qaeda returned to operations under new leadership. This is not to suggest that killing terrorists is a bad thing - on the contrary. But it's not the only thing that matters, and over-emphasizing it wastes resources. The operation that killed Mr. Zarqawi, for example, was not a one-day event. Thousands of hours of intelligence, surveillance and reconnaissance were devoted to the elimination of one man, when units on the ground could have used this time to protect the people from the insurgency that was tearing Iraq apart. Having Osama bin Laden in one's sights is one thing. Devoting precious resources to his capture or death, rather than focusing on protecting the Afghan and Pakistani populations, is another. The goal should be to isolate extremists from the communities in which they live. The best way to do this is to adopt policies that build local partnerships. Al Qaeda and its Taliban allies must be defeated by indigenous forces - not from the United States, and not even from Punjab, but from the parts of Pakistan in which they now hide. ${ }^{63}$

Thus the illusion of "personalization," which leads to a hunt for some "names," distracts policy-makers from structural problems and makes it harder to counter insurgencies in the long run. Indeed, the "heroization" of the ranking leaders in the insurgencies is the main unintended consequence of the personalization of strategy-making. It is not hyperbole to suggest that to be in the hunting list of the US military strategists (or to be a prospective candidate of this list) is an enormously prestigious position for those people living in pro-extremist environments and looking for recognition of others.

\section{Conclusion}

As epitomized in the case of armed drones, military technique has seemed to have a direct impact on the transition of war from state policy to pro-active reflex. The encroachment of technique upon policy in contemporary strategy-making has produced new conceptualizations of war: war not as spatially and temporarily defined means in the service of political objectives and within the framework of policy, but as a series of speed-of-light actions that generally sit on the blurred borders between classical conceptualization of war as a mere instrument of policy and the "capability-based approaches" prevailing in contemporary military strategy-making.

One should note that the rising complexity in relationships between policy and technique, subject and object, fact and value - this rising complexity has made the description of strategy more complicated. As seen in this study, neither traditional instrumentalist nor essentialist variants can provide satisfactory understanding of the relation of technique and strategy. I have suggested that the interaction of technique and the society that uses it will, over time, mutually determine one another in ways that are difficult to foresee, just as the advent of nuclear weapons transformed the conduct of warfare in an astonishing way. One important complexity is yet to be heard from. When many countries have drones, and especially after terrorists acquire drones, the power of drones to determine strategy will not look as deterministic or irresistible as it does today. 


\section{Notes}

1. Please see for full text: http://georgewbush-whitehouse.archives.gov/news/releases/2001/10/p rint/20011007-8.html (accessed April 18, 2013).

2. Lansford, America's War on Terror, 3.

3. Frum and Perle, An End to Evil, 98.

4. Hart, Strategy, 319.

5. Gray, Weapons for Strategic Effect.

6. Mansfield, Theorizing War, 29.

7. Echevarria, Clausewitz and Contemporary War, 81.

8. Hart, Strategy, 321.

9. Echevarria, Clausewitz and Contemporary War, 9.

10. Gray, Modern Strategy, 17.

11. Ibid., 19.

12. Calwell, Small Wars: Tactical Textbook, 90.

13. Singer, Wired for War.

14. Please see: http://wiredforwar.pwsinger.com/index.php?option $=$ com_content\&view $=$ articl e\&id $=69 \&$ Itemid $=71$ (accessed September 12, 2013).

15. Please see: http://wiredforwar.pwsinger.com/index.php?option $=$ com_content\&view $=$ articl e\&id $=51 \&$ Itemid $=2$ (accessed September 12, 2013).

16. The military concept of Revolution in Military Affairs (RMA) is a theory about the future of warfare, often connected to technological and organizational recommendations for change in the US military and others. Especially tied to modern information, communications, and space technology, RMA is often linked to current discussions under the label of Transformation and total systems integration in the US military. One of the central problems in understanding the current debate over RMA is due to many theorists' use of the term as referring to the revolutionary technology itself, which is the driving force of change. Concurrently, other theorists tend to use the term as referring to revolutionary adaptations by military organizations that may be necessary to deal with the changes in technology. Other theorists place RMA more closely inside the specific political and economic context of globalization and the end of the Cold War.

17. Der Derian, Virtuous War.

18. Der Derian, "Virtuous War/Virtual Theory," 771-88.

19. Baudrillard, Simulacra and Simulation.

20. Please see: http://smallwarsjournal.com/blog/swj-quotable (accessed September 12, 2013).

21. Gray, Strategy for Chaos, 121.

22. Singer, "Do Drones Undermine Democracy?"

23. Cloud, "CIA drones broader targets".

24. Mazetti, Way of the Knife.

25. Wise, "Real War, Virtual Cockpit."

26. Ibid.

27. Cole, "Convenient Killing: Armed Drones."

28. "Drone Warfare: American's Killing Machine," The Economist.

29. Mockenhaupt, "We've seen the future."

30. Please see for the full text of the Resolution: http://avalon.law.yale.edu/20th_century/warp ower.asp (accessed May 9, 2013).

31. Singer, "Do Drones Undermine Democracy?"

32. Ibid.

33. Virilio, Open Sky, 43.

34. Kaplan, Readings in the Philosophy of Technology, xiii.

35. From the Latin dromos, signifying a race. Dromology studies how technological developments in speed influence socio-political life.

36. Virilio, Speed and Politics.

37. Virilio, Desert Screen, 43.

38. Ibid., 44.

39. Armitage, Paul Virilio: From Modernism, 104.

40. Paul Virilio, Desert Screen, 110.

41. Ibid., 32 .

42. Ibid., 25. 
43. Ibid., 27.

44. Ibid., 2.

45. Gray, Weapons Don't Make War, 155.

46. Waltz, Spread of Nuclear Weapons, 11.

47. Barnaby, The Nuclear Arms Race, 47.

48. Thompson, "Sources of Exterminism," 3-31.

49. Ross, The Role of Nuclear Weapons.

50. Ibid.

51. Gurcan, "The Evolution of Deterrence," 11-51.

52. Kaplan, Wizards of Armageddon.

53. Ross, The Role of Nuclear Weapons.

54. Ibid.

55. Kurzman, Day of the Bomb, 12.

56. Please see the interview of Leo Szilard, a physicist who helped persuade President Roosevelt to launch the A-bomb project: http://members.peak.org/ danneng/decision/usnews.html (accessed September 13, 2013).

57. Hashmi and Lee, Ethics and Weapons of Mass Destruction, 5.

58. Ibid., 12.

59. Ibid., 12.

60. Becker and Shane, "Secret 'Kill List' Test of Obama."

61. Al-Muslimi, "America Loses Yemeni People."

62. Gurcan, "Seeing the Other Side of the COIN."

63. Kilcullen, "Death Above, Outrage Below."

\section{References}

Armitage, John. Paul Virilio: From Modernism to Hypermodernism and Beyond. New York: Sage, 2000.

Barnaby, Frank. "Nuclear Conflict: A Global Prospect?" In The Nuclear Arms Race - Control or Catastrophe?, edited by Frank Barnaby, and Geoffrey Thomas. London: Frances Printer, 1982.

Baudrillard, Jean. Simulacra and Simulation. Translated by Sheila Glaser. Ann Arbor: University of Michigan Press, 2004.

Becker, Jo, and Scott Shane. "Secret 'Kill List' Proves a Test of Obama's Principles and Will." NY Times, May 29, 2012.

Calwell, Charles E. Small Wars: A Tactical Textbook for Imperial Soldiers. London: reprinted, 1990.

Cloud, David S. "CIA drones have broader list of targets." Los Angeles Times, May 5, 2010.

Cole, Chris. "Convenient Killing: Armed Drones and the Playstation Mentality." Human Rights Watch Report, September, 2010.

Der Derian, James. Virtuous War: Mapping the Military-Industrial-Media-Entertainment Network. New York: Routledge, 2009.

Der Derian, James. "Virtuous War/Virtual Theory." International Affairs 76, no. 4 (October 2000): $771-788$.

"Drone Warfare: America's Killing Machine." The Economist, April 13, 2013.

Echevarria, Antonio. Clausewitz and Contemporary War. Oxford: Oxford University Press, 2007.

Frum, David, and Richard Perle. An End to Evil: How to Win the War on Terror. New York: Ballantine, 2004.

Gray, Colin S. Modern Strategy. New York: Oxford University Press, 1999.

Gray, Colin S. Strategy for Chaos: Revolution in Military Affairs and the Evidence of History. London: Frank Cass, 2004.

Gray, Colin S. Weapons Don't Make War: Politics, Strategy and Military Technology. Lawrence: University of Kansas Press, 1993.

Gray, Colin S. "Weapons for Strategic Effect: How Important Is Technology?.” Occasional Paper, Air War College, January 2001. BiblioScholar, 2012.

Gurcan, Metin. "From Traditional into Tailored: The Evolution of the Concept of Deterrence in the Post-Cold War Era." The Journal of Strategic Studies 9, no. 16 (2011): 11-51.

Gurcan, Metin. "Seeing the Other Side of the COIN: A Critique of the Current Counterinsurgency (COIN) Strategies in Afghanistan." Small Wars Journal, March 11, 2011. http://smallwarsjou 
rnal.com/jrnl/art/seeing-the-other-side-of-the-coin-a-critique-of-the-current-counterinsurgencycoin-strategi (accessed October 20, 2013).

Hart, Basil H. Liddell. Strategy. London: Faber, 1967.

Hashmi, Sohail H., and Steven P. Lee. Ethics and Weapons of Mass Destruction. New York: Cambridge University Press, 2004.

Kaplan, Fred M. Wizards of Armageddon. Stanford University Press, 1983.

Kaplan, David. Readings in the Philosophy of Technology. Lanham: Kowman and Littlefield, 2004. Kilcullen, David. "Death From Above, Outrage Down Below." New York Times, May 16, 2009.

Kurzman, Dan. Day of the Bomb: Hiroshima 1945. London: Weidenfield and Nicolson, 1986.

Lansford, Tom. America's War on Terror. Burlington: Ashgate, 2009.

Mansfield, Nick. Theorizing War: From Hobbes to Bidio. New York: Palgrave Macmillian, 2008.

Mazetti, Mark. The Way of the Knife: The CIA, a Secret Army, and a War at the Ends of the Earth. New York: Penguin Press, 2013.

Mockenhaupt, Brian. "We've seen the future, and it's unmanned." Esquire Magazine, October 14, 2009.

Al-Muslimi, Farea. "America Loses Yemeni People in Drone War." Al-Monitor, August 11, 2013.

Ross, Andrew L. The Role of Nuclear Weapons in International Politics: A Strategic Perspective. Philadelphia: http://www.fpri.org/footnotes/1405.200905.ross.nuclearweaponsintlpolitics.html (accessed September 19, 2013) Foreign Policy Research Institute, 2009.

Singer, Peter. "Do Drones Undermine Democracy?" New York Times, January 21, 2012.

Singer, Peter. Wired for War: The Robotics Revolution and Conflict in the 21 st Century. New York: Penguin Press, 2009.

Thompson, Edward P. "Sources of Exterminism: The Last Stage of Civilization." New Left Review, no. 121 (1980): 3-31.

Virilio, Paul. Desert Screen. New York: Continuum, 2005.

Virilio, Paul. Open Sky. London: Verso, 1997.

Virilio, Paul. Speed and Politics. Translated by Mark Polizzotti. Los Angeles: Semiotext(e), 2006.

Waltz, Kenneth N. The Spread of Nuclear Weapons: More May Be Better. Adelphi Paper No. 171. London: International Studies of Strategic Studies.

Wise, Lindsay. "Fighting a real war in a virtual cockpit: Drones in Houston help troops fight Iraq, Afghanistan wars." Houston and Texas News, June 27, 2010. 